\title{
THE PALESTINIAN QUESTION
}

Though I have not been to Palestine yet, I feel very passionate about the issue. Not simply because I'm Muslim, or because I'm Arab, but because it's a human issue, and I think it's central to a lot of the problems that we face ... I do believe it's very important for the American population to understand and address, because we're so implicit in the actions of our government, Israeli government, whether we realise it or not, it's our tax dollars that are funding a lot of what's going on, and it's our support, our moral support, our spoken support ... Even though there are verbal condemnations perhaps, but the real ... I mean if your friend does something bad and you give them a condemnation and you keep slipping them $\$ 20$, it's not going to really send the right message though. I just think that we have to, as a nation, wake up to all the issues around us and that's just one of the main ones. (Daniel, male, 22, US born, of Palestinian background, national identity: Muslim American, interviewed in Florida, March 2010.)

In my interview with Daniel in 2010, he pointed out that, although at certain times the United States condemned the Israeli government's excessive aggression against the Palestinians, its blind support for Israel morally and financially was not leading to reconciliation. Daniel's observation appears to be reasonable. In September 2011, Palestinian leaders proclaimed that they would request the United Nations to approve 'the recognition of a full membership of the state of Palestine established on the territories occupied by Israel in 1967, with East Jerusalem as its capital'. ${ }^{1}$ Yet President Barack Obama said that his administration would veto such a ruling. ${ }^{2}$ On 1 November 2011, the member states of UNESCO recognised Palestine. Nearly two-thirds of UNESCO nations defied warnings from Israel and the US to support Palestinian membership. Fourteen members voted against - among them were Australia, the US and Canada - and more than fifty 
countries abstained, including Britain. ${ }^{3}$ The United States cut its fund to UNESCO. ${ }^{4}$

The most contentious issue impacting on the Palestinians is Israel's expansion of its settlement into the Palestinian occupied territories (for example, Gaza). International humanitarian law 'prohibits [an] occupying power [from transferring] citizens from its own territory to the occupied territory' (Article 49, Fourth Geneva Convention of 1949), but Israel contests this law. In addition some scholars have been critical of Israel's practice of zero tolerance towards Palestinians, for example Israel's control of water, its reluctance to grant permission to Palestinians to build homes, the construction of a huge apartheid wall, and Israeli soldiers' aggressive attitudes at checkpoints. ${ }^{5}$

The Palestinian question brings the issue of identity politics to the fore. Kwame Appiah wrote about seven ways that people might talk about identity politics: ${ }^{6}$

- political conflicts may be about who is in and who is out;

- politicians can mobilise identities;

- states can treat people of distinct identities differently;

- people can pursue a politics of recognition;

- there can be social micro-politics enforcing norms of identifications;

- there are inherently political identities like party identifications;

- social groups can mobilise to respond collectively to all of the above.

It occurs to me that what Appiah meant was that most political conflict is about power and entitlement - who gets to govern and why. Richard Jenkins also observed that when 'categories' are imposed and the issue is resources and power (and national identity), the more powerful impose boundaries on the less powerful. ${ }^{7}$ Arguably, in the Israeli-Palestinian conflict, and in the already stratified and categorised structure of Israeli society, Palestinians are positioned as an orientalised 'other'.

So what exactly is the orientalised 'other'? In his book Orientalism ${ }^{8}$ Edward Said observed that the West perceives itself to be powerful and aims to control the East. According to orientalists the West will always remain 'superior' to the 'inferior' East. Said observed that in contemporary world politics people are forced almost on a daily basis 'to declare themselves to be either westerners or easterners. No one seemed to be free from opposition between "us" and "them," resulting in a sense of reinforced, deepened, hardened identity that has not been particularly edifying." Said was a Palestinian Christian who strongly opposed the Israeli occupation of Palestine. He noted that in discussions about the 'Occupied Territories' of Palestine, and the 'continued support of Israel', the world is divided into two: the West (and its allies) and the Muslim/Arab world. The notion of 'westerners' and 'easterners' once again becomes clearer.

But how does the Palestinian question impact on young Muslims of 
Palestinian heritage living in the United States? The fifty-three participants of Palestinian heritage quoted in this chapter defined their identities variously as Palestinian, Palestinian American, Arab American, Muslim American and Muslim Palestinian American. When they spoke about various issues, their comments connected to their identity (discussed later). In this context, it appears that, like Palestinians living in Palestine, the interviewees' identity was neither socially nor politically constructed. It was either based on their observations while residing in the United States or on firsthand experience of their visits to Palestine.

In this chapter, firstly, I briefly discuss the contemporary situation in Palestine. Secondly, I examine the responses of the participants of Palestinian heritage on the question of Palestine (summarised in Table 6.1). Whereas some participants of other ethnic backgrounds also expressed views on the IsraeliPalestinian conflict, I have included here only the opinions of the Palestinian Americans. I think it is important to discuss their views because the 'Palestine question' directly impacts on their identity/identities.

\section{The Palestinian situation}

The people of Palestine have experienced ordeals such as the 1948 war, the 1967 war, the first intifada of 1987 (uprising against Israeli oppression), the Oslo accords, the expansion of Israeli settlement, the Camp David summit, the second intifada of 2000, the separation barrier and the Israeli withdrawal from Gaza, and numerous United Nations resolutions for Israel. Yet the Palestinian question remains unresolved. There has been ongoing violence between Palestinians and Israelis. Since 1967, the pressing issues confronting Palestinians can be divided into the following issues: segregation, economic issues, political issues and military occupation. I now elaborate on each in turn.

\section{Segregation}

Over the years about 420,000 Israelis have settled inside the West Bank and East Jerusalem, and Israel plans to expand this number by several thousand. There are two kinds of settlers: ideological and ordinary (majority) settlers. Ideological settlers have an emotional and religious attachment to the land. They believe that the territory was given to the Jewish people by God, so it is their sacred duty to live there even if it means forcibly removing Palestinians from the land. But the majority of the Israelis are ordinary settlers who take houses offered by the government on cheap ten-year mortgages. One way that Israel extends its occupation is by demolishing Palestinians' homes: bulldozers are used by the Israeli soldiers to force Palestinians out of their valleys, which are the best agricultural lands. Every time Palestinian homes are bulldozed, a 
new town is built for Israeli settlers. By 2007, there were about 190 settlements all over the West Bank. ${ }^{10}$

The settlements are well connected by a network of roads that separate the Palestinian communities. This sort of arrangement enables the settlements to expand. The settlers' homes are often constructed near the best agricultural lands and water resources. These properties are protected by barbed wire, and the settlers are armed inside their area - with further protection by the Israeli military from the outside. According to a commentator, 'The bottom line of this occupation is to make the Palestinians leave the country ... It is a kind of "ethnic cleansing".' The policy makers in Gaza and the West Bank are not Palestinians; they are Israelis and their policies are drafted in a manner that ensures the Palestinians remain confined in small spaces. ${ }^{11}$

Speaking of disparity, Saree Makdisi observed that one of Israel's several policies of control is to contain Palestinian growth and development in East Jerusalem. Makdisi noted that since 1967 many Palestinians have built their houses without official permission. But they have done it at considerable risk. Israeli construction in the occupied territories is state funded, but Palestinians build their housing with their own funds. The owners of illegally built properties are often punished and fined, and their constructions may be demolished. For example, a Palestinian resident, Daoud Abu Kaf, wished to move out of his parents' crowded apartment (ten people were sharing two rooms) in Ras al-Amud, in East Jerusalem. Starting in 1982, he lodged several applications for building permits to build a house next door to his parents. All his applications were denied, so in 1987 he built two apartments without a permit. As soon as he completed the building, officials from the Ministry of the Interior showed up and ordered the demolition of the entire structure within twenty-four hours. ${ }^{12}$

Tobias Kelly identified the Israeli-Palestinian conflict as a 'conflict over legal rights', in which issues of sovereignty, identity and territory are tied to the distinction between those who are entitled to rights and those who are not. ${ }^{13}$ Under the Israeli arrangement an Israeli citizen will always be a citizen whether or not he or she lives in the occupied territories, whereas a Palestinian remains a subject under different authorities. Since 1967, Israeli occupation has allowed a form of 'legal pluralism' to coexist in the occupied territories. Several legal codes, such as Israeli military laws, pre-1967 Jordanian laws, Palestinian Authority laws and Israeli civilian laws, determine the rights of the people of the land. For example, in their everyday lives Palestinian workers have to negotiate with various intermediaries: Palestinian subcontractors, Israeli employers, Palestinian courts, Israeli courts, Israeli soldiers at checkpoints, Palestinian National Authority officials transporting the pass permits issued by the Israeli military authorities, and the NGOs helping Palestinians understand Israeli procedures and dealings with local Palestinian institutions. ${ }^{14}$

In 2005 Israel dismantled its settlements and military posts in Gaza and relocated its settlers. Although Israelis are not visibly present in the Gaza Strip, 
Israel still retains ultimate control over the Gaza border, coastal water and air space, thus creating a virtual prison. After the eviction of the Israeli settlers from the Gaza Strip, Israel built a wall (the Bil'in Wall), twice the height of the Berlin Wall and, at 456 miles (730 kilometres) in length, four times as long, which runs through several villages and disrupts Palestinians' travel for work, education and health care purposes. The wall also separates farmers from their work. An Israeli study found that the wall was erected for confiscation of land and not, as publicised by the government, for security reasons. ${ }^{15}$

The Israeli military said that the Bil'in wall was needed for security and attributed to it a sharp reduction in suicide bombings in Israel. The barrier's opponents say it is primarily an Israeli tool to annex Palestinian land in the absence of a peace agreement. The route, as drawn, confiscates 10 per cent of the West Bank onto the Israeli side of the barrier, including more than half the territory of Bil'in. Due to this barrier, many Palestinians have to reroute their travel arrangements, which has made their lives more difficult. ${ }^{16}$

Israel has set up checkpoints within the West Bank causing the Palestinians to wait many hours in order to travel short distances; thus freedom of movement is denied to Palestinians on a daily basis, such as access to Jerusalem, and to hospitals, clinics and schools. Human rights activists observe that in Palestine about three million civilians are denied freedom of movement and that is a violation of international law (freedom of movement is a fundamental right in the UN Declaration of Human Rights). ${ }^{17}$

\section{Economics}

In 2007, the documentary Occupation 101, directed by Abdallah and Sufyan Omeish, reported on the disproportionate allocation of resources in Palestine: only 10 per cent of the West Bank is populated by Jewish settlers, yet they enjoy special privileges. Whereas Palestinians face water restrictions (for example only two hours' running water a week), the settlers enjoy swimming pools, water, electricity, gas and refuse collection. These services are all denied to the Palestinian people.

Hebron is an Arab city with about 100,000 Arabs and a couple of hundred Jewish settlers. The Jewish settlers in Hebron are allowed to carry rifles, and they have built roads for use as bypasses which Palestinians are not allowed to use. Therefore, Israeli settlers can walk about carrying rifles, intimidate and attack Palestinians, and occupy the Palestinians' houses. Some of the Jewish settlers are politically connected so they can get away with such behaviour. If settlers are accused of murder, very few are tried and even if they are the president gives them an amnesty, they are set free, or their term of imprisonment is shortened. ${ }^{18}$

According to World Bank estimates in 2007, nearly 53 per cent of the Palestinian population was unemployed, with 75 per cent of Palestinians living in poverty (on less than $\$ 20$ a day). ${ }^{19}$ In 2008 , Saree Makdisi pointed out that 
48 per cent of the Palestinian population in Israel was living in poverty compared to 15 per cent of the Jewish population. The infant mortality rate among Palestinians in Israel was 8.4 per thousand compared to 3.6 per thousand among Jews. The number of Jewish religious sites in Israel granted state protection and funding was 135 , while the number of non-Jewish sites was zero. ${ }^{20}$ Furthermore, it has been observed that the refugee camps in Palestine were overcrowded, with up to twenty-five people living in small spaces; there was no place for children to play, no streets but just little alleys. The British journalist Richard Falk and Archbishop Desmond Tutu compared the situation for the general population in Palestine to apartheid in South Africa. Yet even this, Falk thought, was much better than the refugee camps in Palestine. ${ }^{21}$

\section{Politics}

In January 2006 elections were held. The Palestinians voted the PLO-led government out of office and Hamas won a majority of seats. But Hamas could not form a government because it was regarded by the United States and Israel as a terrorist organisation. Hamas's demand for a genuinely independent Palestinian state (which the Oslo accords promised but never delivered) and an Israeli withdrawal to the 1949-67 borders was not acceptable to the US and Israel. ${ }^{22}$ It is interesting to note that the United States advocates democracy worldwide (for example in Iraq) but not in Palestine. The academic S. Sayyid observes that the term 'democracy' can be interpreted variously both in the West and the Orient. In some contexts, pro-democratic western countries deny a genuinely elected democratic government (for example, Hamas in Palestine), and in other contexts Muslim countries justify their military intervention against an elected government, stating that it possesses the 'anti-western nature of Islamism', which 'is a threat to "democracy"' (for example, the military coup against the victory of the FIS in the Algerian elections). ${ }^{23}$

\section{Military occupation}

The world has been shocked by Palestinian suicide bombings; for example, on 9 August 2001 a horrendous attack on a pizzeria in central Jerusalem killed fifteen civilians and wounded 130 people. But critics argue that the Israeli occupation is far more brutal. American media such as Fox News, CNN, CBS, ABC News, the New York Times and the New York Post play a major role in manipulating stories and thereby keeping the American public uninformed of the facts. ${ }^{24}$ In the process, major stories go unreported and news reporting is censored. In Occupation 101, some commentators (including Jewish-Israeli people) said that Palestinians live in constant fear, with high levels of anxiety, loss of hope and a sense of vulnerability because at any time they might be killed. So when oppression becomes unbearable people revolt. Palestinians 
are treated cruelly and tortured, their lands are confiscated, their heritage is destroyed, so their revolt is a legitimate resistance to an occupation..$^{25}$

With 200-300 nuclear warheads, Israel is the fifth largest nuclear power in the world. It is in reality a regional superpower. Israel has the largest navy of any country in the world besides the US. US aid (taxpayers' money) to Israel from 1949 to 1996 totalled $\$ 62.5$ billion. Occupation 101 gave the following data: ${ }^{26}$

- Israeli tanks: 3,930

- Palestinian tanks: 0

- Israeli jet fighters: 362

- Palestinian jet fighters: 0

Israeli and Palestinian casualties from September 2000 to February 2007:

- Palestinians killed by Israelis: 4,009

- Israelis killed by Palestinians: 1,021

- 935 children killed (816 Palestinians and 119 Israelis)

On 27 December 2008 Israel launched air attacks on Gaza in response to rocket attacks commenced by Hamas. The conflict ended on 18 January 2009 after Hamas and Israel agreed to a ceasefire. The casualties during the 22-day Gaza war were as follows: Palestinians: 1,300 dead and 5,100 injured; Israelis: 13 dead and 80 injured. ${ }^{27}$ Another example of Israeli heavy-handedness is that in May 2010, when a flotilla of civilian vessels (carrying humanitarian aid, food and medicine) tried to break the Israeli naval blockade of Gaza, Israeli forces killed nine Turkish activists. Turkey demanded an apology and compensation for the families of the activists. In December 2010, Israeli prime minister Benjamin Netanyahu ruled out making an apology to Turkey, stating, 'We will not apologise, but express our regrets to Turkey. ${ }^{28}$

Some local young Palestinians are keen to migrate to the USA because they are not hopeful that Palestine will ever become an independent state. This was portrayed in the film Amreeka (2009), where a Palestinian schoolboy convinced his reluctant mother to migrate to the USA (after his mother received a US migration document) by saying, 'Do you know how many people dream of this opportunity ... It is better than being prisoners in our own country.' Finally, when they (mother and son) migrated to the US, at the US airport they were asked which country they were from. The mother replied that they did not have a country. It had been an occupied land for forty years.

\section{Participants' observations on the Palestinian issue}

In this section I examine the views of the participants on the Palestinian issue. First, I show the key points of their responses (Table 6.1), and then elaborate on the responses in turn. 
Table 6.1 Views of American Muslims of Palestinian background

\begin{tabular}{|c|c|c|}
\hline $\begin{array}{l}\text { Number of } \\
\text { participants }\end{array}$ & Responses & Key points \\
\hline $6 \mathrm{~m}, 9 \mathrm{f}$ & Being Palestinian is not easy & Differential treatment. \\
\hline $2 \mathrm{~m}, 1 \mathrm{f}$ & Airport experience & Racial profiling. \\
\hline $1 \mathrm{~m}, 1 \mathrm{f}$ & Use of terror techniques & It is dehumanising. \\
\hline $0 \mathrm{~m}, 1 \mathrm{f}$ & No easy access to Jerusalem & Israel decides Palestinian identity. \\
\hline $0 \mathrm{~m}, 1 \mathrm{f}$ & Hijab is the ultimate marker & $\begin{array}{l}\text { They gave me a tough time because of } \\
\text { my hijab. }\end{array}$ \\
\hline $1 \mathrm{~m}, 3 \mathrm{f}$ & It was scary & It is a war zone. \\
\hline $2 \mathrm{~m}, 0 \mathrm{f}$ & $\begin{array}{l}\text { Mention of original owner of } \\
\text { the land }\end{array}$ & Injustice still prevails. \\
\hline $1 \mathrm{~m}, 2 \mathrm{f}$ & Feelings for fellow Palestinians & $\begin{array}{l}\text { Alhamdulillah, we are safe, but we } \\
\text { feel for them. }\end{array}$ \\
\hline $1 \mathrm{~m}, 1 \mathrm{f}$ & It is a human issue & $\begin{array}{l}\text { We should be allowed to raise funds } \\
\text { for Palestine. }\end{array}$ \\
\hline $2 \mathrm{~m}, 0 \mathrm{f}$ & $\begin{array}{l}\text { Placed between a rock and a } \\
\text { hard place }\end{array}$ & $\begin{array}{l}\text { We are hated there because we are } \\
\text { Palestinians and we are Americans. }\end{array}$ \\
\hline $0 \mathrm{~m}, 1 \mathrm{f}$ & Obama under the spotlight & $\begin{array}{l}\text { President Obama did not answer my } \\
\text { question. }\end{array}$ \\
\hline $0 \mathrm{~m}, 3 \mathrm{f}$ & Don't say they are Jews & They are Israelis. \\
\hline $1 \mathrm{~m}, 0 \mathrm{f}$ & No hope for Palestine & $\begin{array}{l}\text { The Israelis won't give up resources, } \\
\text { e.g. water. }\end{array}$ \\
\hline $1 \mathrm{~m}, 1 \mathrm{f}$ & Thank God we live in America & Reflection on freedom in the US. \\
\hline $3 \mathrm{~m}, 1 \mathrm{f}$ & Some optimism & We integrated with the Jewish settlers. \\
\hline $2 \mathrm{~m}, 5 \mathrm{f}$ & No comments & $\begin{array}{l}\text { Never visited. } \\
\text { I went there at a very young age so I } \\
\text { don't remember much. }\end{array}$ \\
\hline
\end{tabular}

The fifty-three participants spoke mostly about their firsthand experiences when visiting or living in Palestine for some time. Most participants said they enjoyed visiting their extended families in Palestine, but they were dismayed at the treatment they received from Israeli soldiers at the airport, borders and checkpoints. A few participants (e.g. Jamila and Waleed) also spoke about other issues that they felt were relevant to the discussion of the 'Palestinian question'.

\section{Being Palestinian is not easy}

Fifteen participants spoke of the Israeli authorities' differential treatment towards them and their family members when they visited Palestine. For example, Ruhee (female, over 30, overseas born, national identity: Arab American) said that when she first visited Palestine in 1997 she had a lot of 
negative experiences when dealing with Israelis and even some Arabs at checkpoints and at the airports. She said, 'It was a new experience for me and I guess when I went the second time with my family, with my mother and sisters, it wasn't that much of a surprise because I had received my first dose earlier.' On her next visit to Palestine in 2000 with her mother and sisters, Ruhee said that her sisters were very disturbed by the Israeli authorities' treatment of her mother:

My two sisters and I, we were the only people riding the bus after we left the airport, you know, to go to Jerusalem. And my mother, because she was not a US citizen then, she had to go on a different bus, so for us we felt it was very unfair. You know, this is our mother, and so it was very difficult to explain to my younger sisters as well. So again this is an obstacle and a challenge that we overcame at that time, but in retrospect, just trying to think about what the people go through that live there, it's very tough ... the hardships that they're going through day in and day out.

I held [out] the blue US passport, yes I was put on a bus that was air-conditioned but they [the Israeli guards] weren't nice. I would not describe my experience as being treated with respect. But for my mother, again, this was nothing because she grew up there, she's been in that situation for quite a bit of her life. It didn't come as a shock to her, more than it came for us ... But hopefully things are better there. To be honest with you I don't have any desire, at least at this time, to go visit, just because of that bitter experience. (Interview, Florida, March 2010)

Fawaz (male, 17, US born, national identity: Arab American), who visits Palestine almost every year, described similar experiences of differential treatment:

It's so much fun to visit family there, but you can't leave the house. It's very complicated when we go there.

Because my dad got us a Palestinian citizenship, so when you go there, it's horrible. Yeah, there are two different ways. There's the Palestinian [way, through Jordan] and there's the American way [through Tel Aviv]. It may be like three or four hours from Jordan and they [the Israeli guards] won't let us in. There's a lot of checkpoints because we have also an Israeli car and if you have a Palestinian passport, you're not allowed to drive an Israeli car ... My cousins, they don't have Palestinian citizenship, they drive that and everything ... It's very hard ... the way they treat us is horrible. (Interview, Michigan, April 2010)

Aaneesah (female, 17, US born, national identity: American Muslim, Palestinian) gave a similar account of her ordeal:

Yeah, I go to Palestine every year through Jordan. We have to go through the border, which over there is not like the borders over here. It's horrible, it takes a whole day 
and it's hot. They have buses, un-air-conditioned in the heat, 100 degrees outside. Like five checkpoints and they take your luggage and they throw it in a huge area and everyone has to go find their luggage and pick it up and toss it onto another bus, and you pay and keep paying and paying and paying until they get there. It's only about 2 miles to our destination in Palestine. (Interview, Florida, March 2010)

Apart from the border ordeal, Aaneesah said that sometimes at the checkpoints they had to pay a price for being jubilant:

Sometimes if you're doing something that they [Israeli security guards] don't like or whatever, they'll just tell you 'Okay, well, ten-minute punishment, you have to sit here for ten minutes, you can't go through.' Yeah, like two years ago we were going to a wedding once and they came along and they were angry that everyone was happy and they said, 'Okay, ten-minute punishment', and they put the bus on the side.

Most participants were critical of Israeli treatment towards them at the borders, particularly at the Israeli-Jordanian border, though they loved to visit their relatives in Palestine. And a few were so frustrated with their treatment that they felt discouraged from obtaining a Palestinian ID card. For example, Rameez (male, 16, US born, national identity: Palestinian) said:

I'm from the West Bank. Yeah, Ramallah doesn't have much tension. I went there a year ago. Oh, it's changed a lot from last time. I mean like more buildings have gone up, there's more Jews all over the place and there's like borders everywhere, there's always checkpoints. You have to carry a passport everywhere. Sometimes the Israeli soldiers at the checkpoints give you problems. I have seen them treating my grandfather badly at the Jordanian border when we were trying to enter Palestine ...

I won't take the hawiyya card [Palestinian identity card]. I don't want to settle in Palestine. (Interview, New York, November 2009)

Speaking of his ordeal at the River Jordan crossing checkpoint, an AmericanPalestinian traveller said that in 2007, after being detained for several hours, he was denied access to Palestine and deported back to Jordan. Apparently the Israeli security guards/soldiers had discovered that the traveller had a hawiyya card which had not been activated. The traveller had entered Israel before with his US passport, but they refused to hear his arguments that the border was only for foreigners, and that he was a Palestinian. ${ }^{29}$ The next day, he was held at the Allenby Bridge for not possessing the tasreeh that, they informed him, his mother must have had several years ago. Later he was allowed entrance to Palestine. The traveller then acquired a Palestinian hawiyya card and tasreeb when he was at the West Bank. ${ }^{30}$

Palestinians are not only subjected to many hours' delay at the checkpoints. Sometimes men are ordered at gunpoint to take off their clothes. ${ }^{31}$ In 2010, the 
Tikun Olam website reported that some Israelis not only uprooted Palestinian villages and harassed Palestinians at checkpoints; they also converted the names of many places from Arabic to Hebrew, and now they are 'judaizing Palestinian East Jerusalem'. For example, Nilin, the site of protests against the West Bank Barrier, will become Kiryat HaSefer. Critics say that the Hebrew names are designed to convey to Palestinians the message that Israel is in control. It would also convey that the soldiers and border crossing personnel were not protecting a Palestinian area but Israeli territory. ${ }^{32}$

\section{Airport experiences}

Abdul (male, 17, US born, national identity: Palestinian American) said, 'They held my brother at the airport for six hours [in Palestine]. 'Cos you know how Israel is really close friends with America? So they [Israelis] think the same but even worse over there' (interview, Florida, March 2010). Jamila (female, 18, overseas born, national identity: Muslim Palestinian) commented:

I have US citizenship, so I can go through Tel Aviv airport. I was interrogated for seven hours. By myself, I didn't go with my parents ... They sent me to fifteen different supervisors; everyone said that they were sending me to their supervisor and they asked me the same ten or so questions, like 'Who's your father, who's your mother, who's your grandfather, what was his name?' Things I wouldn't even know, like 'Who's your great-great-grandfather?' I don't know who my great-great-grandfather is. (Interview, Florida, March 2010)

Waleed (male, 30, overseas born, national identity: Palestinian American) lived in Palestine for five years in the 1990s. He said:

Sure, yeah, the US Patriotic [sic] Act definitely has impact on us; my last name being Mohammad, that to them stands out very clearly. As far as airport screenings, extra security [is concerned,] as a Palestinian, we're pretty much used to that because of the way Israelis inspect us at their airport. So even though it might have been something new here in the States, in general for us it was something we got used to, so it didn't bother us that much. (Interview, New York, November 2009)

In Chapter 3, I discussed how some participants in this study felt frustrated by the US authorities' racial profiling at airports (under the Patriot Act). So in the context of racial profiling by the Israeli authorities, Waleed was not upset because, as a Palestinian, he had encountered differential treatment before at Tel Aviv airport. Abdul observed that, because Israel is an ally of the US, such profiling (or even worse treatment) can be expected. 


\section{Use of terror techniques}

Medina (female, 16, US born, national identity: Arab American) said that she was from Jenin in Palestine and her town was generally safe. But she felt intimidated when she went near the border where she saw jeeps full of Israeli soldiers. Medina said:

If I want to visit my family, and they're a little far away, it's going to take us twice the time, plus we have to stop at checkpoints and there's always things like soldiers who have these big guns...

Once I was visiting my relatives in a taxi with my mother, brothers and sisters. So on the way sometimes the Israeli soldiers, they take the paths that people usually take and they bulldoze huge rocks onto them so that they [our cars and taxis] can't pass, just like to annoy us, to cause trouble for us. So there was a long line of taxis of other people waiting; it was a main route but it was closed off. So some men had shovels in their taxis and cleared the road.

But all of a sudden, maybe ten jeeps came out of nowhere and the children started running out and they [the jeeps] started stopping all the cars; some cars got away, other cars were stopped; we were at the beginning of the line so we were stuck there of course. And then they started opening the taxis to see if there were any young men in there because they wanted to see who was helping to do that [clear the road].

They opened our taxi boot and my brother, he was like sixteen, he looked like he could go and help out with that so they pulled him out of the car and one of the soldiers started talking to him in Hebrew. My brother couldn't understand, and the soldier, he started pointing the gun at his head, saying 'Did you do this, did you do this?' and then the taxi driver came out of the car and tried to explain to him [the Israeli soldier] that he didn't do it, that he was too young, and then they let him go. But it was very, very scary. I thought my brother was going to die. (Interview, New York, November 2009)

Minhaj (male, 16, US born, national identity: ' 75 per cent Palestinian and 25 per cent Colombian') said:

I've been there, last year actually, in the summer. I went to Palestine and Jordan. I have relatives in both ... Checkpoints, yeah ... While I was there, a guy, an Israeli soldier stopped our taxi for no reason and he made us come out of the car and he was talking to me in Hebrew, but I didn't really understand. He thought I was giving him attitude and he pulled out his gun; it was devastating. And I just showed him my [American] passport and he was like 'Sorry, sorry', and he let me go. (Interview, Michigan, April 2010)

Other anecdotes and photographs posted on websites reveal similar ordeals of travellers inside Palestine. The photographs are vivid and have immediate 
impact on the viewers. For example, a photo taken by a traveller on 1 June 2006 showed people in cars who had been waiting for several hours on their way to Ramallah. ${ }^{33}$ The caption mentioned that the Israeli military authorities often close down roads throughout Palestine on a whim. This leads to several hours of backed-up traffic, 'an experience that is both dehumanizing and inconvenient'. ${ }^{34}$ At Israeli checkpoints in Palestine the local Palestinians (including the children and elderly) are often subjected to harassment, sexist insults and inhumane treatment.

Further inconvenience at the checkpoints was described by a local Palestinian, Jarrar, who lived and worked in Ramallah, but he and his wife and their twoyear-old son used to visit his parents in Jenin. They used to get dropped off at the Hawara checkpoint, which, he said, 'is one of the most difficult in the West Bank. It takes sometimes four to five hours to pass it, if at all. More than once people are sent back, without any reason. ${ }^{35}$ After Israel imposed further restrictions, Khaled Jarrar and his family visited their parents at Jenin less frequently. Jarrar took a couple of photos of the checkpoint at Hawara, which showed the barbed wire fence next to the path that those who want to cross the checkpoint from either side have to use. He commented that the soldiers did not let them go until they had looked at their checkpoint photos. 'One of the soldiers, a young woman, suddenly felt she needed to defend herself and her comrades by saying they have to protect their country and that it is legitimate to fight terrorists! ${ }^{36}$ Anecdotes reveal that travellers' suffering during peacetime can be exhausting but during crises it can lead to fatalities. For example, during the second intifada in 2000, sixty-eight pregnant women were unable to access hospitals and were forced subsequently to give birth at checkpoints; as a consequence, four women died and thirty-four suffered miscarriages. During 2001 and 2002, about 74 per cent of the forty-six Palestinian deaths occurred because of the denial of access to medical facilities. ${ }^{37}$

\section{Access to Jerusalem}

Jamila (female, 18, overseas born, national identity: Muslim Palestinian) spoke of restrictions people face when they visit Jerusalem:

We went to Jerusalem and we wanted to go and pray, but we weren't allowed in because they said that we weren't Muslims; so we had to prove ourselves as Muslims to the Israeli soldiers and that was very disrespectful, you know, for someone who is going to their holy land to pray. It should be a thirty-minute drive, but because of the checkpoints and stuff, it's a three-hour drive and you have to switch buses continuously because taxi drivers can only drive in a certain area. So it's really hard to go through things like that and then you go to Bethlehem. Actually the day we were in Bethlehem two people, Palestinians, were killed. 
Jamila continued with her grievances:

A lot of the times when you want to go to Israel to visit the beautiful places like Kaffa and the beach and the historical places, Palestinians can't go because you have to be an Israeli to go; but we are allowed to go because we have US citizenship. So it's really hard trying to find someone to take you to go because you want to see this place that you are coming to visit for this first time. (Interview, Florida, March 2010)

On the disparate treatment of Palestinians in their everyday lives, Saree Makdisi wrote:

It is, however, the Israelis, not the Palestinians, who decide what identity is conferred on which Palestinian, and they make the decision ... family life, intimately personal spaces, the nature (and the very existence) of the family home, and even personal identity - who one is, where one can go, where one can live and work. ${ }^{38}$

Makdisi noted that all these factors are politically motivated and founded on the 'distinction between someone who happens to be Jewish and someone who does not'. ${ }^{39}$ Makdisi further said that if a Jewish baby is born in Jerusalem (or in Israel or in the Israeli settlements in the occupied territories), he or she is automatically granted a birth certificate and a state identity number (similar to the US social security card). However, if a Palestinian baby is born in Jerusalem with one parent who is a Jerusalem resident and the other a resident of the West Bank, the baby is not automatically granted the same privilege. Moreover, Palestinian babies born in the occupied areas are not granted the same rights as Jewish babies born there. For example, a Jewish child born in the settlement areas of the West Bank is issued an Israeli identity card and a Palestinian child a West Bank one. ${ }^{40}$

Speaking of the suffering of Palestinian adults, Makdisi discussed the case of a Palestinian couple. In 1996, Hala, a Palestinian resident of Jerusalem, married Odeh, a Palestinian resident with Jordanian citizenship. Hala submitted an application for family reunion so that they could live together. The Israeli authorities can take several years to approve such an application. In the meantime, Odeh was caught in Jerusalem without a permit, so he was expelled to Jordan. When Hala's baby was born, according to the standard procedure the Israeli Ministry of Interior did not give her an identity number. When Hala and her baby went to visit Odeh in Jordan, the Israeli soldiers recorded her baby on an exit permit so it was only with tremendous difficulty that Hala and her baby were allowed to return to Jerusalem (through several applications and appeals), because the baby did not have an Israeli identity number. ${ }^{41}$

Some of the Palestinian participants in this study said that their extended families had settled in Jordan. But in Jordan (though it is an Arab country) 
displaced Palestinians are treated as the 'other'. For example, on 11 December 2010, there was a soccer game between the Palestinian team Wihdat and a Jordanian team, Faisali. Most of Faisali's players and fans are from native Jordanian Bedouin tribes, whereas most of Wihdat's players and fans are Palestinians who have settled in Jordan. When Faisali lost the game, their fans attacked the Palestinian team and inflicted bodily harm on some of the players. It is alleged the Jordanian police were associated with this violence. Witnesses blamed the police for preventing the Wihdat fans from leaving the stadium when angry Faisali supporters threw stones at them. Many Wihdat supporters said the police were biased against them and reacted to their victory over Faisali, a team that is 'a fertile ground for Jordanian nationalists' ${ }^{42}$ On 11 December 2010, Fox News reported that the clash resulted in 250 injuries among fans of both teams. ${ }^{43}$ There is a long history of violence between supporters of the two teams, originating in decades of tension with Jordan's large Palestinian population.

Jordan's Palestinian population consists of about 1.8 million refugees, including those displaced when Israel was created in 1948 and their descendants. Although most of Jordan's Palestinians - excluding natives of the Gaza Strip - carry Jordanian passports and enjoy citizenship rights unmatched by other Arab host governments, many of them complain that they are barred from taking up security and army posts or holding top positions in the Jordanian government. ${ }^{44}$

\section{The hijab is the ultimate marker}

Sadiqah (female, 23, US born, national identity: Arab Muslim) said that before she started wearing the hijab it was very easy for her to get around and to enter Palestine, but once she started to wear the hijab Israeli soldiers detained her for five hours. She commented, 'Before, I think I [was] perceived as a threat, but this visual identifier completely changed everything, so it became a lot more difficult. They gave me a lot more problems even though I had my American passport.' (Interview, Florida, March 2010)

\section{It is scary}

Shayla (female, 16, US born, national identity: Muslim) said that when she lived in Jerusalem she did not see any fighting, but when they had to cross over to go to a different masjid on the other side, armies would stop them. Shayla said, 'They had their tanks and trucks, it's a little scary' (interview, Florida, March 2010). Similarly, Seerat (female, 16, US born, national identity: Arab American) said that she had lived in Beltunia, fifteen minutes away from Ramallah, which was 'pretty safe': 
But when we went out to the mullah, we had to pass the border where there were the army men, the soldiers. And they did ask us questions. And we answered them politely and we just went in.

And I remember a few times, when I was sleeping, we could hear the planes fly from the Israel part to, I think it was Gaza, or some other place. I remember hearing them, and I remember going into my mom's room and just sleeping with her then. I was scared.

It's really disturbing, it's heartbreaking. Yeah, thank God, my family is fine there. (Interview, Florida, March 2010)

Lisa Haque (female, 16, US born, national identity: Pakistani Palestinian) said that she had not visited Palestine yet, but she showed some awareness of what it was like when she said, 'When I was younger I remember when my grandma came, she had a foot problem too, because they [the Israelis] shot her in the foot. So they [grandparents] had to leave. They lost all their land and everything overseas' (interview, Massachusetts, April 2010).

\section{Mention of the original owners of the land}

Aadil (male, over 30, overseas born, national identity: 'Muslim American of Palestinian heritage') said:

It's a matter of freedom, and the right for people to live peacefully. And when you see on the news the aggravation and the harsh procedure that's used by the Israelis against the Palestinians there, the original owners of the land, you're surprised that injustice is still there. (Interview, Massachusetts, October 2009)

Abdallah (male, 17, US born, national identity: Arab American) commented:

In a nutshell, I was born in New York. My roots are from Palestine. Long story short, my grandparents were kicked out of their original homeland and had to move to USA. My father came here with my grandparents when he was young. But our extended family still lives in Palestine. I've been there I'd say a good four, five, six times. It's my second home. I'm a citizen of that area. I could live there if I want to and I have my ID so ... (Interview, New York, November 2009)

Mateen (male, 15, US born, national identity: Palestinian American) said:

I have never been to Palestine but I watch news with my mom, grandma and grandpa. I watch it with them sometimes, and when I watch what's going on in my country, Palestine, everything going on with Palestinians and the Jewish people. But they don't show much ... I mean the news here [in America] is owned by the Jewish people, so what they do is they block out the majority of the stuff and they show you 
just little bits of stuff of what we're doing, but if you watch the real Arabic news they show you both sides: what the Jewish people are doing to Palestinians and what the Palestinians are doing to the Jewish people. Yeah, America, if they [Americans] don't like somebody they'll turn everybody against them. So they'll do whatever they can to make the other people look bad. (Interview, Michigan, April 2010)

Although the interviewees expressed their identities differently, they spoke passionately about Palestine. Often they used the words 'we', 'us' or 'our' when referring to Palestinians, and 'they' or 'them' for Israel and its ally the United States. The interviewees also alluded to Palestinians as the 'original owners of the land'.

\section{Feelings for fellow Palestinians}

Adiba (female, 23, US born, national identity: Arab American) said that her extended family lived in a peaceful place in Palestine called Beit Hanina. She commented:

Alhamdulillah, it's very calm, it's definitely not what I see on the news. I know what's going on there when I see the wall built and ... and the checkpoints make it harder to get to other towns ... I do feel it, and I've friends who live in those towns that are like war torn, but, alhamdulillah, it's not where I visit. (Interview, New York, November 2009)

Muznah (female, 20, US born, national identity: Arab American) said:

My parents were born in West Bank ... Totally we're always connected every time something happens, we have satellite TV at home so we're watching it as it happens, as it unfolds. We definitely feel with them what they're going through and we sympathise with them ... We try to do fundraisers, we go to demonstrations, we just try to voice our opinions in different ways. Because we can't be there we're kind of helpless in any other way. But we definitely feel with them. (Interview, New York, January 2010.)

Safwan (male, 16, US born, national identity: Muslim Arab) said that he and his family were from Ramallah, which was peaceful and not like the Gaza Strip:

We don't feel it [the oppression] but we know about it. Ramallah to Gaza is about two or three minutes' drive. It's not too big a country but ever since the Jews made it complicated you have to go all around the country just to get there; it takes us two to three hours now. I like Palestine, it's nice ... When there is disturbances we all feel affected of course 'cos these are our people, they're only a few minutes away and we can't help them, we have no power to help them so ... 
When I asked Safwan if he was optimistic about President Obama, he replied:

Well, I was pretty happy because he started focusing on being an ally of Palestine instead of an enemy. So I thought, I had hopes that maybe the war would end ... but so far I'm not seeing much change from him. He also spoke for Palestine initially, I guess he's quiet now that he got his job ... his presidential seat, he doesn't care much, it looks like, yeah. (Interview, New York, November 2010)

Critics observe that pro-Israel lobby groups have control of US foreign policy decision making, so the US president may not have much control over his actions. For example, the American Israel Public Affairs Committee (AIPAC) lobby group is powerful. It has millions of dollars to spend on influencing American politicians. Congressmen fear that if they oppose what Israel wants, then in the next election they might be defeated. ${ }^{45}$

Some participants believed that the US, being a strong ally of Israel, blindly supports Israel even though it is considered by critics to be a regime that represses Palestinians. For example, at the United Nations conference on racism in Durban, South Africa, in September 2001, the Israeli and the US delegates jointly walked out when the original draft resolution to the conference expressed a 'deep concern' at the 'increase of racist practices of Zionism and anti-Semitism' and referred to the emergence of 'movements based on racism and discriminatory ideas, in particular the Zionist movement, which is based on racial superiority'. The resolution also made direct criticisms of Israeli repression against the Palestinians in the West Bank as a 'new kind of apartheid, a crime against humanity'. ${ }^{46}$

\section{It is also a human issue}

Mehjabeen (female, 25, US born, national identity: Palestinian) perceived that during any natural calamities on American soil, such as Hurricane Katrina, the US government is keen to collect donations to help the victims, but not when it comes to American Muslims collecting donations for destitute people in Palestine:

It's upsetting and lots of people have been branded as terrorists because of them raising money for Palestine and for Gaza. But when we had the hurricane and that hit, everyone is sending money over and being able to donate; text messages are set up and we can't even set up a text message donation for Gaza ... In Gaza we have got children who are starving. We have got women who are starving, and we have got men without jobs.

Once the USA Patriot Act was passed in 2001, several Islamic charitable organisations were banned. For example, in July 2004, the Holy Land 
Foundation for Relief and Development was charged with supporting the militant Palestinian group Hamas with money laundering and conspiracy. ${ }^{47}$ Ten interviewees in this study told me that two of their Palestinian mentors had been deported for sending funds to Palestine. So raising funds for the destitute people of Gaza is regarded as a security threat to the US. On some occasions, however, Americans have been allowed to raise funds for Palestine (discussed later). Mehjabeen continued with her observations:

America should be fair with the situation because it's bombs against rocks. Who is going to win really, honestly? We are not going to come out on top, not now at least, but the future with the grace of Allah and the will of Allah we will, but it's difficult ... we are looked at like we are the terrorist and we don't even have anything to go by, except for our little rocks and our little pebbles. (Interview, Michigan, May 2010)

Mehjabeen's Palestinian identity came to the fore when she stated, 'We [Palestinians] won't give up, but the problem is that we are already labelled as "terrorists".'

\section{Between a rock and a hard place}

Naved (male, 17, US born, national identity: American) said:

I am from Silwad, it's a small city [in Palestine]. I have been there three times in my life ... I hated it. They [the Palestinians] thought I was a Jew ... When I went to school over there they hurt me and stuff, they threw rocks. Yeah, that's why I don't like going there any more. I took it like a man and I didn't hit them back. I went home ... I didn't cry!

Oh, yeah they do that 'cos you come from America, then they start going crazy, they ask you all these questions, 'Oh, enter from America', this and that ... they go crazy. If they ask in Arabic if you like Bush and if you say 'Yes', then they won't like you, they'll be cool with you but they won't like you. (Interview, Florida, March 2010)

Another participant, Ahmed (male, 19, US born, national identity: American Palestinian), who travels between USA and Palestine on a regular basis, said that, when he and his family lived in Ramallah, during wartime it was 'scary' for all of them. I asked him if there was electricity and running water in Ramallah. He replied, 'Yeah, Ramallah's good.' Regarding the checkpoints, Ahmed said, 'Yeah, too much search.' When I asked him if he felt bad about what was happening in the West Bank, he replied, 'Yeah, I feel bad, everybody must feel bad.' Regarding the economic conditions in Palestine, he said, 'There is no work.' Talking about security searches, Ahmed said that he is searched at 
the Palestinian checkpoints, and when he comes from Palestine he faces more searches at US airports. I asked him about the profile of Hamas in Palestine. Ahmed replied, 'Hamas is doing good work in the hospitals and other places. Good work but they are getting a bad name from the US and Israel' (interview, New York, November 2009).

\section{Obama under the spotlight}

Jamila (female, 18, US born, national identity: Muslim Palestinian) said that she attended a town hall meeting in the USA where President Obama came to give a speech:

President Obama said he would take seven questions from the audience. So I happened to be the first person and I asked him about why America financially funds Israel and Egypt, although they have human rights violations. President Obama didn't end up answering my question, but I didn't ask the question because I wanted an answer. I know the answer. I asked the question because I wanted to create awareness of the conflict. (Interview, Florida, May 2010)

Political analyst Halim Rane has observed that, in President Obama's efforts to establish peace in the Middle East, he requested the Israeli government to stop the construction of settlements on Palestinian territory. Yet his request was not reinforced by any threat of aid reduction or sanctions against Israel. So the continuation of Israeli settlement in the Palestinian territory is detrimental to the peace process with the Muslim world. ${ }^{48}$

In April 2010, the Christian Science Monitor reported that in 2008 a Congressional Research Service study found that since 1949 the US has given Israel more than $\$ 101$ billion in aid, including $\$ 53$ billion in military help, $\$ 31$ billion in economic aid, and $\$ 15$ billion in other grants. Although Israel is a relatively rich country, it gets slightly more than the annual $\$ 2.6$ billion US aid going to impoverished Afghanistan. Between 1949 and 2008 Israel received a total of $\$ 101$ billion in US aid. The US is far more generous to Israel than to the next largest recipients of its aid, Egypt, Pakistan and Jordan. ${ }^{49}$ Other reports revealed that, as part of his $\$ 3.8$ trillion budget request to Congress for fiscal year 2011, President Obama has asked for $\$ 3$ billion in military aid to Israel - a \$225 million increase from the previous year. The foreign aid bill includes much more than US security assistance to Israel. By contrast President Obama has requested only $\$ 550.4$ million in aid for the Palestinian Authority. ${ }^{50}$

Between 29 June and 20 July 2010, the University of Maryland and Zogby International surveyed 3,976 people from Egypt, Jordan, Lebanon, Morocco, Saudi Arabia and the United Arab Emirates. Large numbers of respondents called for a halt to US aid to Israel. The overwhelming majority would agree to a peace deal with Israel but a firm majority did not believe Israel wants peace. 
A small percentage said Arabs should fight on even if Israel withdraws from territory occupied in $1967 . .^{51}$

\section{'Don't say they are Jews, say they are Israelis'}

On her identity, Fariha (female, 16, US born) said, 'I am mostly American, half Arab, and I am Muslim.' To my question 'How would Muslims contribute to harmony with the wider society?' Fariha replied:

I have not been to Palestine yet. My dad has kept going there regularly. I don't know, besides being nice people, being fully approachable and maybe not saying things that get people, I don't know, man, sometimes people are just really horrible. Sometimes my dad will go and say common things like 'Oh, those Jews' or something. And I think that you need to sort of cut down on that. Like if you mean Israel's latest policy, then say Israel's policy, don't just label everyone. Also, Muslims need to work together more, be more cohesive ... If we want to take part in a service project in the broader community, we should all get up and get behind it and not squabble about it ... I think we should volunteer and get out there and do things. (Interview, Michigan, April 2010)

Maysoon (female, 16, US born, national identity: Palestinian American) passionately spoke of her humanitarian activities during the Gaza War:

Actually, yeah, last year [December 2008] we raised about \$70,000 for Gaza. We had a lot of fundraising things, we had activists come from outside and speak to us. We had a big event in a hall where we invited a lot of people and we had poetry and all that stuff. We raised a lot of money for it and we'd always like to keep everybody aware of what's going on there. Yeah, I'm very involved on the Palestinian issue.

Maysoon also spoke of the Jewish involvement in the Gaza rally:

Well, sometimes we go to protests and during the Gaza siege we had a lot of protests in Manhattan. There was always like another protest for the Israelis. We probably had thousands of people and they probably had like ten. Actually we had some Jewish people on our side. Yeah, there were a lot of Jews that were also against [Israeli occupation of Palestine]. (Interview, New York, November 2009)

Regarding the conflict between Israel and Palestine, Maysoon clarified:

It's Zionism we're against, not Judaism. They'll [the Israeli protestors] be holding signs saying, oh, 'Hamas are terrorists' and stuff like that. But then there'll be Jewish people that are with us, they have signs holding up, there's sometimes even Jewish speakers that come and they speak at our protests. Yeah, they are not supportive of 
the Zionists. In Palestine it's not really an issue of religion, it's more of [nationalism], it's nationalistic.

The Harvard Jewish scholar Sara Roy observed that historically the dominant framework of the Israeli-Palestinian conflict and US foreign policy towards Israel is still supported by mainstream Jewish institutions, including the Jewish lobby. However, recently the US government's support for Israel has been criticised by some mainstream non-Jewish and Jewish Americans. They may have to pay a price for being critical, but the slow movement has already started. For example, former US president Jimmy Carter was criticised for publishing his book Peace not Apartheid, where he focused 'on the nature of the Israeli occupation and the Palestinians' consequent deprivation'. ${ }^{52}$ Roy noted that Carter's use of the word 'apartheid' in association with Israel caused fourteen members of the Carter Center advisory board to resign in protest. His critics branded him an anti-Semite and even a Nazi sympathiser. However, his book sold around 300,000 copies and was on The New York Times bestseller list for some time. ${ }^{53}$

In 2006, the political scientists Professor John J. Mearsheimer and Professor Stephen M. Walt from the University of Chicago and Harvard University respectively wrote an article titled 'The Israel lobby' in the London Review of Books (after The Atlantic withdrew its agreement to publish it), which subsequently became a bestselling book, The Israel Lobby and US Foreign Policy. In their book, Mearsheimer and Walt exposed the extent of the influence that the Israel lobby group, Christian fundamentalist groups and certain individuals have on US foreign policy. The authors further asserted that the Israel lobby influenced the USA to make certain decisions, such as the Iraq war, which have proved disastrous in the long run. ${ }^{54}$

In the media too, overt criticism of the Israeli occupation of Palestine was considered taboo. But this trend is slowly changing. For example, in January 2009, CBS's 60 Minutes ran a segment called 'Is peace out of reach?', which was highly critical of Israeli control and oppression of Palestinians. The reporter, Bob Simon, himself a Jew, was severely criticised by some Jewish members of his community. Similarly, the Palestinian activist Mustafa Barghouti and a Jewish American peace activist, Anna Baltzer, appeared on The Daily Show with Jon Stewart on 28 October 2009. Both Barghouti and Baltzer were critical of the Israeli occupation and spoke of the possibilities of peaceful co-existence in the region. ${ }^{55}$ The documentary Occupation 101 also included the voices of Jewish academics and human rights activists in Israel, who criticised Israel's heavy-handedness against the Palestinians, for example, Rabbi Arik Ascherman (Rabbis for Human Rights Jerusalem), Neta Golan (Israeli Peace Activists), Rabbi Rebecca Lillian (Jewish Peace Forum) and Professor Ilan Pappe (Israeli historian, Haifa University). ${ }^{56}$ 


\section{No hope for Palestine}

When I asked Kabeer (male, 16, US born, national identity: American Arab) about his visit to Palestine, he replied: 'That was three years ago. I visited with my family and it was not fun going through the border.' I then asked him, 'So do you think there's hope? One day Palestine will be an independent country?' Kabeer replied, 'No, I don't think so because I don't think there'll be any country due to the resources, like the fresh water that they have under Palestine and Israel, I don't think they're [Israel] willing to give that up' (interview, Michigan, April 2010).

\section{'Thank God we live in America'}

Two participants of Palestinian background appreciated that they lived in the United States, where there is freedom of speech and freedom of movement. For example, Murad (male, 17, US born, national identity: Muslim Palestinian American) commented:

I have been to Palestine, many times. Just the feeling of being on lockdown that you're not used to in America because you're free, you can do whatever you want here. You have no one controlling where you go or what you do, besides your parents of course. But when you go there you've got to always have your passport on you, always checkpoints, anywhere you go, even entering the country they give you a hard time. (Interview, Florida, March 2010)

Sadiqah (female, 23, US born, national identity: Arab Muslim) said:

Yes, I have been to Palestine many times. My father is from Hebron. Oh, it's very difficult, because I think growing up in the States, it's a very open society and you try to be politically correct all the time. When you go over there, there's just so much hatred on both sides and you feel torn because you don't like to hate anybody but when you see the injustice over there, it's really hard to keep yourself away from falling into that hating of the Israeli Zionists. It's very difficult. Very trying. (Interview, Florida, March 2010)

Murad had multiple identities but, because he appreciated living in the US, he leaned towards his American identity, whereas Sadiqah identified herself as Arab Muslim though she expressed her frustration over the identity politics of that region. ${ }^{57}$ 


\section{Some optimism}

Waleed (male, over 30, US born, national identity: Palestinian American) offered his views:

Between the ages of ten to fifteen I lived in Palestine [in the early 1990s]. It was relatively quiet compared to these days and during that time I learned the language and the culture and the religion... At the age of ten I'd barely spoken any Arabic so my grandparents were upset at that so they convinced my parents to go back home, so I learned the language, the culture, the religion. I lived with my mom along with my siblings, while my dad continued working here.

The village I lived in was all Palestinians; we had a couple of Jewish settlements surrounding our village and going to the actual city of Jerusalem we would pass through security checkpoints and we ... we'd mingle with Jewish residents also. I spoke Hebrew ... just a few phrases. English was a common language.

The fact is I still relate to it and probably would even move there [Palestine] eventually in old age. (Interview, New York, November 2009)

Waleed has a positive image of Palestine from when he lived there at a much younger age. So he thinks he will to go back to Palestine in his old age. Nabil (male, 20, US born, national identity: Palestinian) also lived in Palestine in the 1990s and did not encounter much resistance from the Israelis:

I lived right next to Nablus, a city in the West Bank. I lived there for about five years from '94 to '99. At the time I lived there it was pretty peaceful. It started picking up, like, we left when the second intifada was starting to take place. They had curfews where you can't leave the house after seven o'clock and stuff and a lot of people got into trouble because of that. Small things were like, if some trouble happens in the town people come and random people get arrested and stuff like that. And I had confrontation with Israelis where they'd push you around and stuff. Nothing ever too extreme, alhamdulillah. (Interview, Florida, March 2010)

Rehman (male, 15, US born, national identity: Arab American) also visited Palestine, when he was ten. He said, 'My visit was good fun. We visited Palestine, Jordan, Saudi Arabia and Iraq’ (interview, Michigan, April 2010).

\section{No comments}

Seven Palestinian-background participants had no comments on the topic of Palestine. Most of them either had not visited Palestine, or had lived there at a very young age. For example, Abbas's grandparents settled in Jordan, his father was born in Jordan and Abbas was also born there. They have never 
been to Palestine and they moved to the USA in around 2005 (interview, New York, January 2010). Faeezah had been to Palestine only once, at the age of eight, so she did not remember much about it (interview, New York, January 2010). Haneef said, 'My father's Palestinian and my mother is Egyptian. I've never left the country [USA] actually' (interview, Florida, March 2010).

\section{Conclusion}

The Israeli-Palestinian issue is complex. Security is an issue for both Israel and Palestine. The Israelis' concern is mainly territorial security in their occupied land and the fact that they are such a minority in the region. So the Israeli authorities have toughened their border control and checkpoint scrutiny. It appears from the experiences of the interviewees that Israeli soldiers often go overboard with their security procedures, which the interviewees described as 'dehumanising'. Whereas most interviewees looked forward to visiting their extended families in Palestine, in spite of all the discomforts, a few felt discouraged about visiting Palestine or even keeping some sort of contact with Palestine (for example, some would not opt for a Palestinian ID card). Some participants were critical of the US government's blind support of Israel and Israel's continued aggression against the Palestinians. Finally, in this whole episode of Israel's aggression against Palestine, it is reassuring to see that some participants did not label all Jews as aggressors. And these participants appreciated those Jewish people who were advocating the rights of Palestinians.

\section{Notes}

1. 'Palestinian bid for statehood at UN a "distraction": U.S. President Barack Obama', Siam Daily News website, 14 September 2011, http://www.siamdaily news.com/world-breaking-news/2011/09/14/palestinian-bid-for-statehood-at-un-adistraction-u-s-president-barack-obama/, accessed 24 May 2012.

2. Ibid.

3. 'How UNESCO countries voted on Palestinian membership', Guardian website, 1 November 2011, http://www.guardian.co.uk/world/2011/nov/01/unesco-coun tries-vote-palestinian-membership, accessed 29 May 2012.

4. 'Palestine recognized as the full member of UNESCO, Israel and US condemns', CNN News website, 1 November 2011, http://www.latestcnnnews.com/palestinerecognized-as-the-full-member-of-unesco-israel-and-us-condemns.html, accessed 24 May 2012.

5. Saree Makdisi, Palestine Inside Out: An Everyday Occupation (New York: W. W. Norton, 2008); George Bisharat, 'Israel and Palestine: a true one-state solution', Washington Post, 3 September 2010, p. A21; Cherien Dabis (dir.), Amreeka (National Geographic, 2009). 
6. Kwame Anthony Appiah, 'The Politics of Identity', Daedalus, Fall 2006, pp. 15-22.

7. Richard Jenkins, Social Identity, 3rd edn (London: Routledge, 2008).

8. Edward Said, Orientalism (New York: Vintage, 1979).

9. Ibid., p. 335.

10. Abdallah Omeish and Sufyan Omeish (dirs), Occupation 101: Voices of the Silent Majority (Triple Eye Films, 2006).

11. Occupation 101; Makdisi, Palestine Inside Out.

12. Makdisi, Palestine Inside Out, pp. 106-7.

13. Tobias Kelly, Law, Violence and Sovereignty among West Bank Palestinians (Cambridge: Cambridge University Press, 2006); Leila Farkash, review of Kelly, Law, Violence and Sovereignty among West Bank Palestinians, American Ethnologist 35:3 (2008), pp. 3009-12.

14. Ibid.

15. Occupation 101.

16. Scott Wilson, 'Israeli court orders rerouting of barrier; decision backs Palestinian villagers', Washington Post, 5 September 2007, p. 16.

17. Occupation 101.

18. Ibid.

19. Ibid.

20. Makdisi, Palestine Inside Out, p. 102.

21. Occupation 101; Philip Weiss, 'Tutu: issue is the same in Palestine as it was in South Africa, “equality"', Mondoweiss website, 11 April 2010, http://mondoweiss.net/2010/04/tutu-issue-is-the-same-in-palestine-as-it-was-in-south-africaequality.html, accessed 24 May 2012.

22. Makdisi, Palestine Inside Out, p. 280.

23 S. Sayyid, 'Mirror, Mirror: Western Democrats, Oriental Despots?' Ethnicities 5:1 (2005), pp. 30-50, see p. 39.

24. Occupation 101.

25. Ibid.

26 Ibid.

27 Paddy Allen, 'The Israeli attacks on Gaza', Guardian website, 19 January 2009, http://www.guardian.co.uk/world/interactive/2009/jan/03/israelandthepalestinians, accessed 24 May 2012.

28. 'No apology to Turkey: Netanyahu', World News Australia website, 28 December 2010, http://www.sbs.com.au/news/article/1453251/No-apology-to-Turkey:-Netan yahu, accessed 24 May 2012.

29. 'Attempted to enter at the Jordan River crossing on 12/16/07 and was turned away. Entered through the Allenby bridge on 12/17/07', Right to Enter website, http://www.righttoenter.ps/previous_cases.php?id=563, accessed 24 May 2012.

30. Ibid.

31. 'IDF kashers checkpoints, replacing Arabic with Hebrew names', Tikun Olam website, http://www.richardsilverstein.com/tikun_olam/2010/11/06/idf-kasherscheckpoints-with-hebrew-names/, accessed 24 May 2012. 
32. Ibid.

33. ' 3 hour wait near Hawara checkpoint in Nablus, Palestine', Flickr website, 1 June 2006, http://www.flickr.com/photos/einkarem1948/3664604620/, accessed 24 May 2012.

34. Ibid.

35. Khaled Jarrar, 'At the checkpoint', This Week in Palestine, March 2007, p. 62.

36. Ibid.

37. UN-OCHA, Israeli-Palestinian Fatalities since 2000: Key Trends (New York: United Nations Office for the Coordination of Humanitarian Affairs, 2007).

38. Makdisi, Palestine Inside Out, p. 102.

39. Ibid.

40. Ibid. pp. 113-14.

41. Ibid. pp. 114-15.

42. 'Jordanian football violence leaves 250 hurt', SBS World News Australia website, 11 December 2011, http://www.sbs.com.au/news/article/1439581/Jordanianfootball-violence-leaves-250-hurt, accessed 25 May 2012.

43. 'Jordanian, Palestinian soccer fans clash', Fox News website, 11 December 2010, http://www.foxnews.com/world/2010/12/11/jordanian-palestinian-soccer-fans-cla sh/, accessed 25 May 2012.

44 Ibid.

45. Occupation 101.

46. Chris Marsden, 'Israel and US walk out of UN Conference on Racism', World Socialist Web Site, 6 September 2001, http://www.wsws.org/articles/2001/ sep2001/isr-s06.shtml, accessed 25 May 2012.

47. Abdus Sattar Ghazali, Islam and Muslims in the post-9/11 America: A Source Book (Modesto, CA: Eagle Enterprises, 2008), p. 36; see also Louise Cainkar, Homeland Insecurity: The Arab American and Muslim American Experience after 9/11 (New York: Russell Sage Foundation, 2011), pp. 184-5.

48. Halim Rane, Islam and Contemporary Civilisation: Evolving Ideas, Transforming Relations (Melbourne: Melbourne University Publishing, 2010).

49. David R. Francis, 'US can raise the pressure on Israel without cutting aid', Christian Science Monitor website, 5 April 2010, http://www.csmonitor.com/Commentary/ David-R.-Francis/2010/0405/US-can-raise-the-pressure-on-Israel-without-cuttingaid, accessed 25 May 2012.

50. 'Obama budget includes $\$ 3$ billion in Israel aid', Near East Report website, 23 February 2010, http://www.aipac.org/NearEastReport/20100223/obama_budget_ includes_three_bil_israel_aid.html, accessed 25 May 2012.

51. Michael Jansen, 'Obama's popularity plunges in Arab world,' Irish Times, 7 August 2010, p. 11.

52. Sara Roy, 'Reflection on the Israeli-Palestinian Conflict in U.S. Public Discourse: Legitimizing Dissent', Journal of Palestinian Studies 39:2 (2010), pp. 23-38.

53. Ibid. p. 27.

54. Ibid. 
55. Ibid. 28-9.

56. Occupation 101; see also John L. Esposito, The Future of Islam (New York: Oxford University Press, 2010), p. 85.

57. See also Leila Farsakh, 'Exiles and Home,' Human Architecture 6:2 (2008), pp. 79-90. Leila Farsakh wrote about her feelings for Palestine while living in exile. 